\title{
HOME RANGE AND HABITAT USE BY KEMP'S RIDLEY TURTLES IN WEST-CENTRAL FLORIDA
}

\begin{abstract}
JEFFREY R. SCHMID, 1,2 Department of Wildlife Ecology and Conservation, University of Florida, Gainesville, FL 32611, USA, and National Marine Fisheries Service, Southeast Fisheries Science Center, Miami, FL 33149, USA

ALAN B. BOLTEN, Archie Carr Center for Sea Turtle Research, University of Florida, Gainesville, FL 32611, USA

KAREN A. BJORNDAL, Archie Carr Center for Sea Turtle Research, University of Florida, Gainesville, FL 32611, USA

WILLIAM J. LINDBERG, Department of Fisheries and Aquatic Sciences, University of Florida, Gainesville, FL 32611, USA

H. FRANKLIN PERCIVAL, Department of Widdife Ecology and Conservation, University of Florida, Gainesville, FL 32611, USA

PAUL D. ZWICK, Department of Urban and Regional Planning, University of Florida, Gainesville, FL 32611, USA

Abstract: The Kemp's ridley turtle (Lepidochelys kempii) is an endangered species whose recovery depends in part on the identification and protection of required habitats. We used radio and sonic telemetry on subadult Kemp's ridley turtles to investigate home-range size and habitat use in the coastal waters of west-central Florida from 1994 to 1996. We tracked 9 turtles during May-August up to 70 days after release and fou.nd they occupied $5-30 \mathrm{~km}^{2}$ foraging ranges. Compositional analyses indicated that turtles used rock outcroppings in their foraging ranges at a significantly higher proportion than expected, based on availability within the study area. Additionally, turtles used live bottom (e.g., sessile invertebrates) and green macroalgae habitats significantly more than seagrass habitat. Similar studies are needed throughnut the Kemp's ridley turtles' range to investigate regional and stage-specific differences in habitat use, which can then be used to conserve important foraging areas.
\end{abstract}

JOURNAL OF WILDLIFE MANAGEMENT 67(1):196-206

Key words: compositional analysis, Florida, GIS, habitat use, home range, Kemp's ridley turtle, Lepidochelys kempii, radiotelemetry, sonic telemetry.

The Kemp's ridley turtle is the most endangered marine turtle species. Human consumption of eggs and incidental capture in shrimp trawls have been identified as the primary populationdecline causes (Hildebrand 1982, Magnuson et al. 1990). Initial efforts to conserve Kemp's ridley turtles concentrated on protecting the primary rookery at Rancho Nuevo, Tamaulipas, Mexico, where almost the entire adult female turtle population comes ashore to nest. In recent years, efforts have focused on reducing turtle captures in the United States and Mexican shrimp fisheries. These conservation efforts during the past 3 decades may be benefiting the turtles, since the number of nests recorded at Rancho Nuevo has steadily increased since the mid-1980s (Márquez et al. 2001). Nevertheless, the species' status remains precarious. The 3,778 nests observed in 2000 (Márquez et al. 2001 ) is still significantly lower than the estimate of 90,000 nests in 1947 (Magnuson et al. 1990) Furthermore, human encroachment in critical habitats, such as coastal foraging grounds, may threaten Kemp's ridley turtle recovery (Thompson et al. 1990, U.S. Fish and Wildlife Service and National Marine Fisheries Service 1992).

\footnotetext{
1 E-mail: jeffs@conservancy.org

2 Present address: The Conservancy of Southwest Florida, 1450 Merrihue Drive, Naples, FL. 34102, USA.
}

Immature Kemp's ridley turtles are distributed in U.S. coastal estuaries from Massachusetts to Texas. Biological and physical attributes of areas inhabited by Kemp's ridley turtles have been used to characterize turtle habitat preferences. However, these preferences have been described without regard to the availability of habitat and as such have resulted in inferences about use but not preference (Thomas and Taylor 1990). Radio and sonic telemetry have been used to describe localized Kemp's ridley turtle movements, but no investigation has estimated the time turtles spent using the habitats in a given area. Estimates of resource availability and use are necessary for identifying coastal foraging habitats that are essential to Kemp's ridley turtle recovery (Thompson et al. 1990, U.S. Fish and Wildlife Service and National Marine Fisheries Service 1992). Furthermore, these data are needed to test habitat preference hypotheses. After habitat use and preferences are established, inferences can be made concerning particular habitat type selection. Our purpose was to investigate Kemp's ridley turtle home range and habitat use in the coastal waters of west-central Florida.

\section{STUDY AREA}

We conducted our study in Waccasassa Bay, located on the west coast of Florida and east of the Cedar Keys (Fig. 1), 1994 to 1996. Waccasassa Bay's northern and eastern boundaries are delin- 


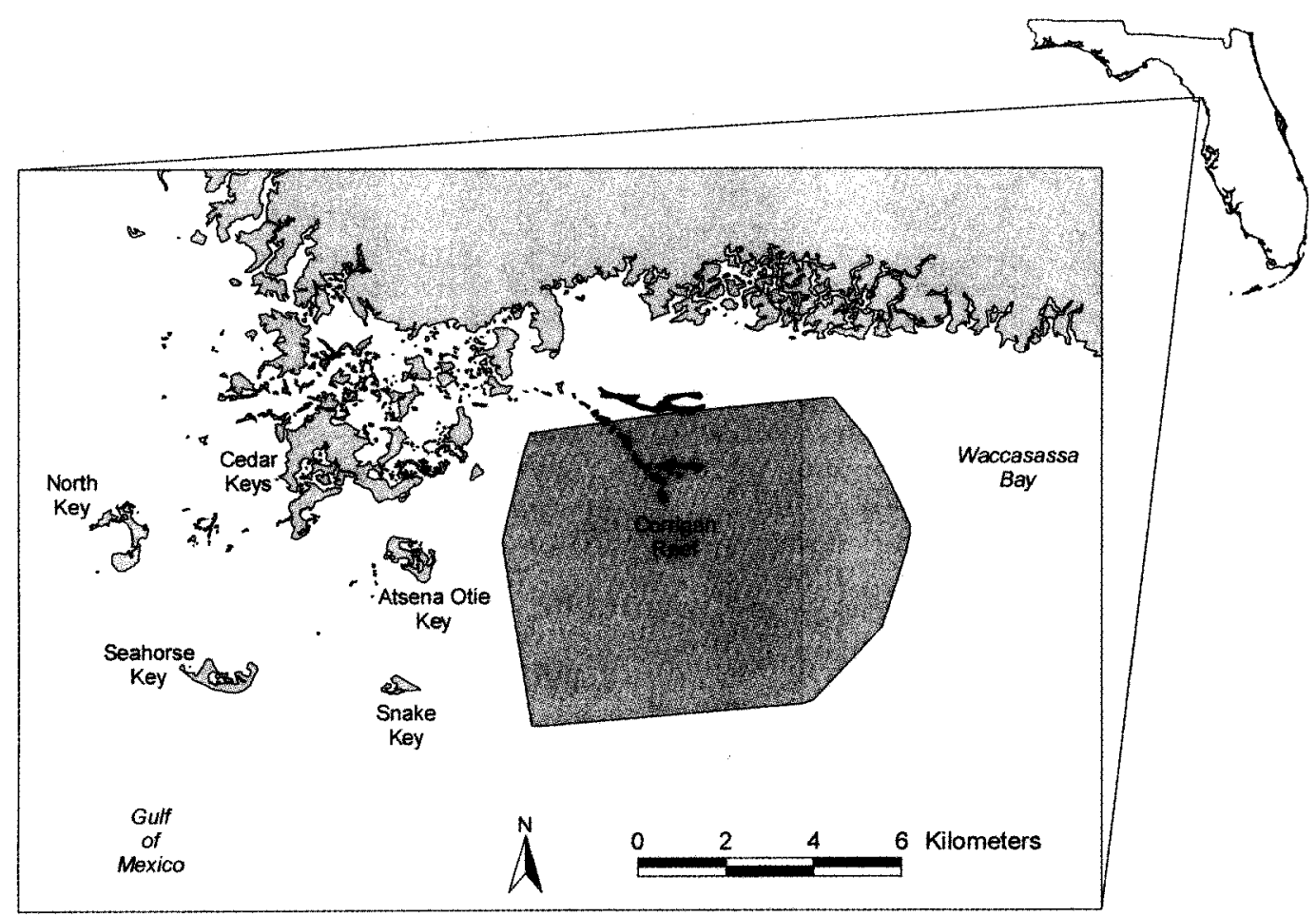

Fig. 1. Map of west-central Florida, USA, showing the study area (crosshatched polygon) for Kemp's ridley turtle habitat analyses (1994-1996). The study area represents a composite minimum convex polygon home range for the 9 turtles tracked in our study.

eated by undeveloped saltmarsh coastline. The Waccasassa River drains into the northeastern region and is the major freshwater contributor to this estuarine embayment (Wolfe 1990). We concentrated our efforts in the western portion of the bay, which is bordered by the Cedar Keys archipelago and the fishing community of Cedar Key. The southern region is open to the Gulf of Mexico's marine waters. Corrigan Reef, a series of oyster and shell bars, is the prominent geographic feature in the northwestern Waccasassa Bay region.

\section{METHODS}

\section{Capture and Tracking}

We used a large-mesh entanglement net $(65-\mathrm{m}$ length, 51-cm stretch mesh, and 20 meshes deep) to capture Kemp's ridley turtles near Corrigan Reef. A detailed description of the capture sites and methods is provided by Schmid (1998). After measuring and tagging, we instrumented turtles with a sonic transmitter (CHP-87-L; Sonotronics, Tucson, Arizona, USA) and a tethered, buoyant radiotransmitter (MOD-050 with a TA-7 antenna; Telonics, Mesa, Arizona, USA).
We released instrumented turtles in the capture area and began tracking after a 24-hr acclimation period. We used radiotelemetry to obtain bearings for long-distance tracking and sonic telemetry to pinpoint the turtle locations. We collected hourly turtle locations by maneuvering the tracking vessel within $10-20 \mathrm{~m}$ of the turtle and recording the tracking vessel's location with differentially corrected Global Positioning System (DGPS). Accuracy of the DGPS locational estimate was approximately $5 \mathrm{~m}$ as determined from the variability associated with a fixed position of the vessel.

We estimated distances to instrumented turtles from the sonic signal strength at half gain on a directional hydrophone and receiver (Dukane Corp., St. Charles, Illinois, USA). The tracking vessel was anchored near an instrumented turtle between location acquisitions. We conducted tracking opportunistically in 1994, and most data were collected during the day. In 1995, we systematically monitored turtles for 4 tracking intervals of approximately $12 \mathrm{hr}$ each, so that observations were collected each hr over 2 24-hr cycles. At least $24 \mathrm{hr}$ elapsed before we initiated the second tracking interval, at least $48 \mathrm{hr}$ elapsed before 
we initiated the third interval, and at least $24 \mathrm{hr}$ elapsed before we initiated the fourth interval. After the intensive tracking period, we opportunistically located the turtles to establish their presence in the study area.

\section{Home-Range Area}

We used the computer program HOME RANGE (Ackerman et al. 1990) to calculate indices of autocorrelation. The minimum time to independence for the locational data was 4-6 hr (Schmid et al. 2002). Therefore, home-range estimates requiring statistical independence could not be used because of hourly location nonindependence. We used HOME RANGE to calculate the $100 \%$ minimum convex polygon (MCP) coordinates and area for each turtle (Table 1). We converted turtle locations and home-range coordinates to point and polygon themes, respectively, with ARCVIEW version 3.0 (Environmental Systems Research Institute 1992-1996) geographic information system (GIS) software. Home-range polygons were buffered $100 \mathrm{~m}$ to encompass turtle locations on the corners and perimeter. We used a composite home range of turtles tracked in 1995 to delineate the area for habitat mapping (Porter and Church 1987). We overlaid east--west transects spaced at 100-m intervals on the studyarea polygon. We located sampling sites at $100-\mathrm{m}$ intervals along each transect. Transects with turtle locations at or near the endpoints were extended an additional $100 \mathrm{~m}$.

\section{Habitats}

Habitat Characterization.-We used sediment (Lambe and Whitman 1969) and biotic characteristics (Continental Shelf Associates, Inc. and Mar- tel Laboratories Inc. 1985, Wolfe 1990) to characterize habitats within the study area. We classified benthic substrates as shell (mollusc shell fragments retained by a No. 4 sieve), sand (shell and rock particles and coralline algae sediments passing through a No. 4 sieve and retained on a No. 200 sieve), mud (silt and clay particles passing through a No, 200 sieve), and rock (limestone bedrock outcroppings). We classified biological assemblages as seagrass (Thalassia testudinum, Syringodium filiforme, Halodule wrightii, Halophila englemanni), green macroalgae (Caulerpa spp., Udotea congulata, Halimeda incrassata), red macroalgae (Gracilaria spp.), and live-bottom (sessile invertebrates of the phyla Porifera [sponges], Cnidaria [gorgonians], Bryozoa [bryozoans], and Chordata [tunicates]). We mapped benthic habitats within the study area in 1996. We deployed a grab sampler shipboard to collect substrate at each sample site. We used a wet-sieving method (American Standards for Testing and Materials 1993) to sort the benthic substrates in the field. Approximately $125 \mathrm{ml}$ of wet sediment was rinsed through No. 4 and No. 200 sieves with seawater. We estimated shell, sand, and mud percent composition from visual inspection of the portions remaining within the sieves. We determined the presence of rock with a sounding pole. Habitat Data Analyses.-We generated a GIS base map of the benthic substrates from the habitat database. We determined the substrate at each sample site from the highest percentage of mud, sand, or shell, and in these strata's absence, the presence of rock. We constructed habitat maps by overlaying biological assemblages on the substrate base map. We layered assemblages hierarchically with the least-abundant layer above the moreabundant layers, such that assemblages on the

Table 1. Summary of Kemp's ridley turtles used in home range and habitat analyses at Cedar Keys, Florida, USA (1994, 1995).

\begin{tabular}{|c|c|c|c|c|c|c|}
\hline Tag code & Turtle ID & $\begin{array}{c}\text { Carapace } \\
\text { length }(\mathrm{cm})\end{array}$ & $\begin{array}{c}\text { Mass } \\
(\mathrm{kg})\end{array}$ & Contact duration & $\begin{array}{c}\text { No. of } \\
\text { locations }\end{array}$ & $\begin{array}{c}\text { Convex } \\
\text { polygon }\left(\mathrm{km}^{2}\right)\end{array}$ \\
\hline \multicolumn{7}{|l|}{1994 season } \\
\hline PPY $168-169^{a}$ & LK1 & 43.4 & 11.8 & 30 May-15 Jul & 69 & 5.8 \\
\hline PPY 172-173 & LK2 & 54.0 & 23.1 & 19 Jun-1 Jul & 47 & 12.9 \\
\hline PPY 175-176 & LK3 & 46.2 & 14.1 & 9 Jul-26 Jul & 50 & 29.5 \\
\hline PPY $177-178$ & LK4 & 36.6 & 7.7 & 1 Aug-27 Aug & 53 & 11.4 \\
\hline \multicolumn{7}{|l|}{1995 season } \\
\hline PPY 183-184 & LK5 & 41.9 & 11.3 & 4 May-15 Jun & 57 & 25.9 \\
\hline PPY 185-186 & LK6 & 46.0 & 13.4 & 22 May-27 Jul & 65 & 18.0 \\
\hline PPY 191-192 & LKK & 49.9 & 19.0 & 19 Jun-24 Jul & 59 & 19.7 \\
\hline PPY 195-196 & LK8 & 34.7 & 5.9 & 14 Jul-22 Sep & 58 & 6.7 \\
\hline PPY $197-198^{b}$ & LK9 & 49.3 & 16.3 & 5 Aug-19 Aug & 54 & 4.9 \\
\hline
\end{tabular}

a Originally tagged 3 Oct 1991, recaptured 20 Sep 1992, and recaptured 2 May 1994.

b Originally tagged 1991 (marginal mark), recaptured 19 Sep 1993, and recaptured 5 Aug 1995. 
top masked those below. We converted habitat maps from vector to raster $(100 \times 100 \mathrm{~m}$ cells $)$ format with the ARCVIEW Spatial Analyst extension.

Compositional analysis (Aitchison 1986) considers the animal rather than the telemetry location as the sample unit and therefore avoids the locational data's non-independence problem (Aebischer et al. 1993). Aebischer et al. (1993) recommend compositional analysis of habitat preferences at 2 levels. The first level is each turtles' home-range habitat composition compared to the overall study area's habitat availability, which corresponds to Johnson's (1980) secondorder habitat-selection level. We determined study-area habitat availability as the proportion of each habitat within the composite home range of turtles tracked in 1995, and home-range habitat composition as the proportion of each habitat type within each turtles' home range. The second level recommended by Aebischer et al. (1993) is habitat use at each turtle's locations compared to the habitat availability in its home range, which corresponds to Johnson's (1980) third-order habitat-selection level. We estimated habitat use by each turtle from the proportion of locations within each habitat in the turtle's home range. We replaced null proportions with 0.0001 as suggested by Aebischer et al. (1993).

We applied analyses of habitat preference by turtles to the benthic substrate basemap and all possible biological assemblage layer combinations. Percent compositions of use and availability for the benthic substrate combinations and biological assemblages are provided in Schmid (2000:164-181). We analyzed use and availability data using a SAS Institute (1989) command file (Ott and Hovey 1997). We used multivariate analysis of variance (MANOVA) to test whether differences in log-transformed use and availability proportions were significantly different from zero $(P<0.05)$. We determined significance levels from randomization because of the potential nonnormality of the multivariate data (Aebischer et al. 1993, Carroll et al. 1995). In the event of significant nonrandom use, we compared all possible habitat-type pairs for a given combination and ranked habitat in order of use. We used the pattern of $t$ values in the ranking matrix to assess significant differences $(P<0.05)$ in habitat type use.

Aebischer et al. (1993) recommended sample sizes $\geq 10$ and preferably $\geq 30$ when conducting compositional analyses of an animal population's habitat. The number of individuals must be greater than the number of habitat types to show a significant difference using MANOVA (Aebischer et al. 1993, Miller et al. 1999). Nine turtles would be the absolute minimum for habitat-preference analyses in our study since there was a maximum of 8 habitat types. While this sample size would be considered low for compositional analysis, it is relatively large when compared to other investigations of Kemp's ridley turtles employing radio and sonic telemetry. Byles (1988) tracked 2 Kemp's ridley turtles and Danton and Prescott (1988) tracked 1 turtle, each during a single season, while Morreale and Standora (1992) tracked 26 turtles over a 4-year period (4-10 turtles/yr). Tracking the movements of an animal that spends most of its time underwater is labor intensive and costly, thus limiting the sample size and the duration of data collection. Sample sizes were inadequate to test for differences in habitat use between years. All means are presented \pm 1 standard deviation (SD).

\section{RESULTS}

Five Kemp's ridley turtles were instrumented from May-August 1994, and 10 turtles were instrumented from May-November 1995. Of this total, only turtles with $>\mathbf{4 0}$ locations were used in analyses (Table 1). Turtles not included either moved out of the study area $(n=4)$ and/or lost their transmitters prematurely $(n=2)$. Three of the turtles that left the area returned within a week, and the fourth moved offshore after passage of a cold front in November.

\section{Home-Range Area}

We located Kemp's ridley turtles in the Cedar Keys study area up to 66 days after initial capture (Table 1). Two turtles (LK1, LK9) were recaptures from previous tagging studies in Waccasassa Bay and had been at large for $3-4$ years prior to telemetric monitoring. These turtles and 3 others (LK2, LK4, LK8) occupied 4.9-12.9 km² home range areas with a gradual increase in size during their respective monitoring periods (Fig. 2). In contrast, 4 turtles (LK3, LK5, LK6, LK7) occupied $18.0-29.5 \mathrm{~km}^{2}$ home-range areas with periodic $10-20 \mathrm{~km}^{2}$ increases in home-range size. Home-range area was not significantly correlated with carapace length or mass.

\section{Habitat Availability}

The composite of turtle locations collected during the 1995 season produced a $46.44 \mathrm{~km}^{2}$ studyarea polygon (Fig. 1) with 4,808 sample sites. We classified $81.0 \%(n=3,893)$ of the sites as sand, 


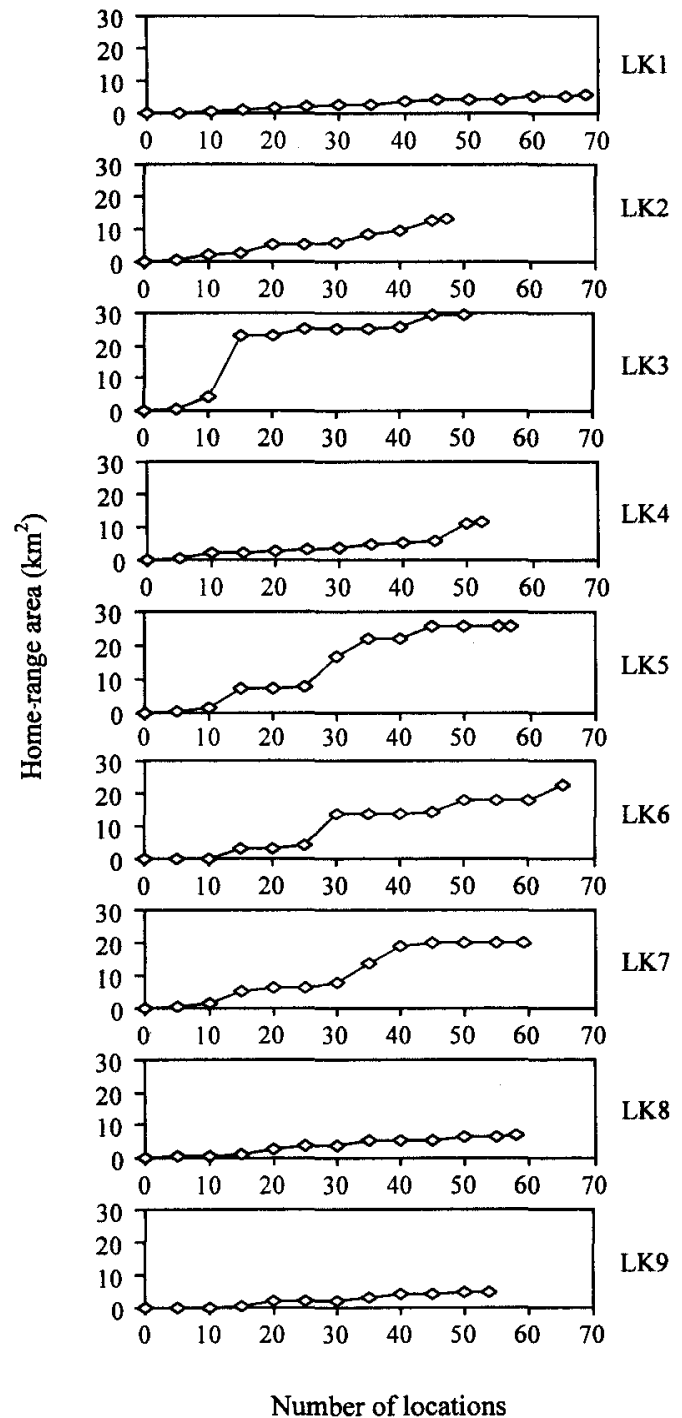

Fig. 2. Home-range area vs. number of locations for Kemp's ridley turtles in west-central Florida, USA (1994-1995).

$14.2 \%(n=684)$ as rock, $2.1 \%(n=103)$ as shell, $2.0 \%(n=94)$ as mud, and $0.7 \%(n=34)$ as clam aquaculture leases. Clam lease sites were not included in habitat analyses since no data were collected for these locations.

We recorded the presence of rock at $53.0 \%(n=$ $2,063)$ of the sites classified as sand, 18.1\% $(n=$ $17)$ of the sites classified as mud, and $10.7 \%(n=$ 11) of the sites classified as shell. For the sites classified as shell, $71.8 \%(n=74)$ were comprised of oyster (Crassostrea virginica), most of which were shells of dead individuals.
We collected green macroalgae species at $27.4 \%(n=1,306)$ of the sample sites; seagrasses at $17.8 \%(n=850)$; live bottom at $9.0 \%(n=431)$; red macroalgae at $7.3 \%(n=346)$; and brown macroalgae at $0.3 \%(n=14)$. The principal seagrass assemblage components were Halodule wrightii $(61 \%)$ and Halophila englemanni $(32 \%)$. The principal green macroalgae assemblage components were Caulerpa prolifera $(53 \%)$ and Udotea congulata (21\%). Red macroalgae were difficult to identify in the field, but the assemblage was composed primarily of Gracilaria spp. The seagrass species were predominantly collected on sand substrate, whereas higher percentages of algae species were collected on rock. Sponge $(64 \%)$ and gorgonians $(22 \%)$ were the principal components of the live-bottom assemblage. We collected live-bottom components on rock or sand with rock outcroppings. We probably underestimated the available rock substrate and the associated biological assemblages, given the preponderance of outcroppings in sites classified as sand.

\section{Habitat Use}

The benthic substrate with the highest meanuse proportion was sand $(79.6 \pm 5.3 \%$ for home ranges and $78.5 \pm 6.0 \%$ for locations), followed by rock $(16.6 \pm 4.2 \%$ and $18.7 \pm 3.7 \%)$. However, we recorded the presence of rock outcroppings in a high proportion of the used sand bottom $(59.0 \pm$ $9.0 \%$ and $54.2 \pm 11.0 \%$ ). Green macroalgae had the highest mean-use proportion for biological assemblages $(24.0 \pm 20.9 \%$ and $22.8 \pm 22.4 \%)$, followed by seagrasses $(13.0 \pm 16.9 \%$ and $10.2 \pm$ $13.2 \%)$, and live bottom $(10.3 \pm 1.8 \%$ and $12.1 \pm$ $3.6 \%)$. There was higher variability in green macroalgae and seagrass use by individual turtles as indicated by the relatively high standard deviations. We probably underestimated the use of rock substrate and the associated biological assemblages, as indicated for habitat availability.

\section{Habitat Preference}

Rock had the highest ranking for primary substrate combinations (Table 2). With the addition of individual biological assemblages, rock was ranked highest in all significant second-order analyses, and mud was ranked highest in significant third-order analyses. Rock and sand were used significantly more than mud for all second-order analyses and significantly more than shell for third-order analyses. Furthermore, green and red macroalgae were used more than shell for third-order analyses of individual biological assemblages. 
Table 2. Combinations of benthic substrates $(a-c)$ and individual biological assemblages $(d-g)$ for compositional analyses of Kemp's ridley turtle habitat preference in west-central Florida, USA, 1994-1996.

\begin{tabular}{|c|c|c|c|c|c|}
\hline Dataset & Order & $\Lambda$ & df & $P$ & Rankings (significant differences in parentheses) \\
\hline \multirow[t]{2}{*}{ a) Primary substrates } & Second & 11.98 & 3 & 0.022 & Rock>Sand $>$ Shell>Mud (Rock \& Sand $>>$ Mud) \\
\hline & Third & 13.78 & 3 & 0.021 & Rock $>$ Mud $>$ Sand $>$ Shell (Rock \& Sand $>>$ Sheli) \\
\hline \multirow[t]{2}{*}{ b) Substrates with rock } & Second & 17.29 & 6 & 0.154 & Not significant \\
\hline & Third & 13.55 & 6 & 0.349 & Not significant \\
\hline \multirow[t]{2}{*}{ c) Sand with rock } & Second & 14.11 & 4 & 0.043 & Rock $>$ SandRock $>$ Sand $>$ Shell $>$ Mud (Rock, SandRock, \& Sand $>>$ Mud) \\
\hline & Third & 12.09 & 4 & 0.136 & Not significant \\
\hline \multirow[t]{2}{*}{ d) Seagrass } & Second & 24.20 & 4 & 0.001 & Rock $>$ Sand $>$ Shell $>$ Seagrass $>$ Mud (Rock \& Sand $>>$ Mud) \\
\hline & Third & 12.32 & 4 & 0.053 & Not significant \\
\hline \multirow[t]{2}{*}{ e) Green algae } & Second & 28.42 & 4 & 0.001 & Rock>Sand $>$ Green $>$ Shell $>$ Mud (Rock \& Sand $>>$ Mud) \\
\hline & Third & 14.81 & 4 & 0.048 & Mud $>$ Rock>Sand $>$ Green>Shell (Rock, Sand, \& Green $>>$ Shell) \\
\hline \multirow[t]{2}{*}{ f) Red algae } & Second & 21.79 & 4 & 0.004 & Rock>Sand>Red>Shell>Mud (Rock \& Sand >>Mud) \\
\hline & Third & 14.56 & 4 & 0.047 & Mud $>$ Rock>Sand $>$ Red $>$ Shell (Rock, Sand, \& Red $>>$ Shell) \\
\hline \multirow[t]{2}{*}{ g) Live bottom } & Second & 13.00 & 4 & 0.072 & Not significant \\
\hline & Third & 13.58 & 4 & 0.051 & Not significant \\
\hline
\end{tabular}

For assemblage pairs (Table 3), rock and live bottom were ranked highest in second-order analyses, and mud was ranked highest in significant third-order analyses. Turtles used rock, sand, live bottom, and red macroalgae significantly more than mud in second-order analyses. Turtles used live bottom, green macroalgae, and red macroalgae significantly more than seagrass. For significant third-order analyses, shell was used significantly less than the other bottom types, and mud was used significantly more than seagrass in the green macroalgae-seagrass combination.

For combinations of 3 biological assemblages (Table 4), rock and live bottom ranked highest in second-order analyses, and mud ranked highest for the significant third-order analysis of the green macroalgae-live bottom-red macroalgae combination. Live bottom was ranked the highest in the second-order analysis of all biological assemblages combined. Turtles used rock, sand, live bottom, and red macroalgae significantly more than mud in second-order analyses and significantly more than shell in the third-order combination of seagrass-live bottom-red macroalgae. Furthermore, turtles used live bottom and green macroalgae significantly more than seagrass and live bottom significantly more than red macroalgae in second-order analyses.

\section{DISCUSSION}

\section{Home-Range Area}

Approximately half the Kemp's ridley turtles we tracked occupied small and stable home ranges

Table 3. Combinations of benthic substrates and paired biological assemblages for compositional analyses of Kemp's ridley turtle habitat preference in west-central Florida, USA, 1994-1996.

\begin{tabular}{|c|c|c|c|c|c|}
\hline Dataset & Order & $\Lambda$ & df & $P$ & Rankings (significant differences in parentheses) \\
\hline \multirow[t]{2}{*}{ a) Seagrass-green algae } & Second & 29.45 & 5 & 0.005 & $\begin{array}{l}\text { Rock }>\text { Sand }>\text { Green }>\text { Shell }>\text { Seagrass }>\text { Mud } \text { (Rock \& Sand }>>\text { Mud; } \\
\text { Green }>>\text { Seagrass) }\end{array}$ \\
\hline & Third & 17.57 & 5 & 0.050 & $\begin{array}{l}\text { Mud }>\text { Sand }>\text { Rock }>\text { Green>Seagrass }>\text { Shell (Mud, Sand, Rock, \& } \\
\text { Green }>>\text { Shell; Mud }>>\text { Seagrass) }\end{array}$ \\
\hline \multirow[t]{2}{*}{ b) Seagrass-red algae } & Second & 24.61 & 5 & 0.014 & $\begin{array}{l}\text { Rock>Sand }>\text { Red }>\text { Shell>Seagrass }>\text { Mud (Rock, Sand, \& Red }>>\text { Mud; } \\
\text { Rock }>>\text { Red; Red }>>\text { Seagrass) }\end{array}$ \\
\hline & Third & 14.94 & 5 & 0.105 & Not significant \\
\hline \multirow[t]{2}{*}{ c) Seagrass-live bottom } & Second & 25.89 & 5 & 0.004 & $\begin{array}{l}\text { Live }>\text { Rock }>\text { Sand }>\text { Shell }>\text { Seagrass }>\text { Mud (Live, Rock, \& Sand }>>\text { Mud; } \\
\text { Live }>>\text { Seagrass) }\end{array}$ \\
\hline & Third & 12.70 & 5 & 0.192 & Not significant \\
\hline \multirow[t]{2}{*}{ d) Green algae-red algae } & Second & 34.51 & 5 & 0.002 & Rock>Sand $>$ Red $>$ Green $>$ Shell>Mud (Rock, Sand, \& Red $>>$ Mud) \\
\hline & Third & 16.48 & 5 & 0.085 & Not significant \\
\hline \multirow[t]{2}{*}{ e) Green algae-live bottom } & Second & 31.87 & 5 & 0.003 & Live $>$ Rock>Sand $>$ Green>Shell>Mud (Live, Rock, \& Sand $>>$ Mud) \\
\hline & Third & 15.06 & 5 & 0.123 & Not significant \\
\hline \multirow[t]{2}{*}{ f) Red algae-live bottom } & Second & 21.53 & 5 & 0.012 & $\begin{array}{l}\text { Rock> }>\text { Live }>\text { Sand }>\text { Red }>\text { Shell }>\text { Mud (Rock, Live, Sand, \& Red>>Mud; } \\
\text { Live>>Sand \& Red) }\end{array}$ \\
\hline & Third & 18.92 & 5 & 0.026 & Mud $>$ Live $>$ Sand $>$ Rock $>$ Red $>$ Shell (Live, Sand, Rock, \& Red $>>$ Shell) \\
\hline
\end{tabular}


Table 4. Combinations of benthic substrates and tertiary groupings of biological assemblages (a-d) and afl assemblages combined (e) for compositional analyses of Kemp's ridley turtle habitat preference in west-central Florida, USA, 1994-1996.

\begin{tabular}{|c|c|c|c|c|c|}
\hline Dataset & Order & $\Lambda$ & df & $P$ & Rankings (significant differences in parentheses) \\
\hline \multirow[t]{2}{*}{$\begin{array}{l}\text { a) Seagrass-green algae- } \\
\text { red algae }\end{array}$} & Second & 30.94 & 6 & 0.025 & $\begin{array}{l}\text { Rock }>\text { Sand }>\text { Red }>\text { Green }>\text { Shell }>\text { Seagrass }>\text { Mud (Rock, Sand, \& } \\
\text { Red }>>\text { Mud; Green }>>\text { Seagrass) }\end{array}$ \\
\hline & Third & 17.52 & 6 & 0.142 & Not significant \\
\hline \multirow[t]{2}{*}{$\begin{array}{l}\text { b) Seagrass-green algae- } \\
\text { live bottom }\end{array}$} & Second & 31.70 & 6 & 0.017 & $\begin{array}{l}\text { Live }>\text { Rock }>\text { Sand }>\text { Green }>\text { Shell }>\text { Seagrass }>\text { Mud (Live, Rock, \& } \\
\text { Sand }>>\text { Mud; Live \& Green>>Seagrass) }\end{array}$ \\
\hline & Third & 19.23 & 6 & 0.119 & Not significant \\
\hline \multirow[t]{2}{*}{$\begin{array}{l}\text { c) Seagrass-red algae- } \\
\text { live bottom }\end{array}$} & Second & 30.63 & 6 & 0.023 & $\begin{array}{l}\text { Rock }>\text { Live }>\text { Sand }>\text { Red }>\text { Shell }>\text { Seagrass }>\text { Mud (Rock, Live, \& } \\
\text { Sand }>>\text { Mud; Live }>>\text { Seagrass \& Red) }\end{array}$ \\
\hline & Third & 22.09 & 6 & 0.035 & $\begin{array}{l}\text { Mud }>\text { Live }>\text { Sand }>\text { Rock }>\text { Red }>\text { Seagrass }>\text { Shell (Live, Sand, Rock, \& } \\
\text { Red }>>\text { Shell) }\end{array}$ \\
\hline \multirow[t]{2}{*}{$\begin{array}{l}\text { d) Green algae-red algae- } \\
\text { live bottom }\end{array}$} & Second & 42.11 & 6 & 0.006 & $\begin{array}{l}\text { Live }>\text { Rock }>\text { Sand }>\text { Red }>\text { Green }>\text { Shell }>\text { Mud (Live, Rock, Sand, \& } \\
\text { Red }>>\text { Mud; Live }>>\text { Red) }\end{array}$ \\
\hline & Third & 14.72 & 6 & 0.285 & Not significant \\
\hline \multirow[t]{2}{*}{$\begin{array}{l}\text { e) All biological } \\
\text { assemblages }\end{array}$} & Second & 36.39 & 7 & 0.049 & $\begin{array}{l}\text { Live }>\text { Rock }>\text { Sand }>\text { Red }>\text { Green }>\text { Shell }>\text { Seagrass }>\text { Mud (Live, Rock, } \\
\text { Sand, \& Red }>>\text { Mud; Live \& Green }>>\text { Seagrass; Live }>>\text { Red) }\end{array}$ \\
\hline & Third & 26.24 & 7 & 0.136 & Not significant \\
\hline
\end{tabular}

around Corrigan Reef. The other turtles' home ranges were larger because of occasional movements to other localities around the intertidal oyster reef. These excursions may represent turtles searching for more favorable foraging areas. Considerable spatial overlap occurred in individual Kemp's ridley turtle's home ranges, particularly around the southern portion of Corrigan Reef, but data for each turtle were collected during different periods. Interactions among turtles (such as competition or territoriality) are unknown, and no evidence suggests mutually exclusive ranges. On 1 occasion, the sonic signals of 2 turtles were received while tracking a third turtle, indicating a close proximity among the turtles, given the sonic transmitters' limited range. However, all turtle locations would have to be collected at the same time to determine any possible associations among turtles (White and Garrott 1990).

Turtles used relatively confined areas during the 2-week intensive monitoring period and continued to occupy these areas for at least 2-3 months. Kemp's ridley turtles may, therefore, reside within this region during their seasonal occurrence (Apr-Nov; Schmid 1998), but long-term tracking (i.e., $6-8 \mathrm{mo}$ ) is needed to determine the extent of their home range within a season.

Temperatures in the northern Gulf of Mexico's nearshore waters decline with the onset of winter, and marine turtles must move to favorable thermal regimes. Kemp's ridley turtles return to Corrigan Reef between seasons, as evidenced by the multiannual recaptures of 2 turtles prior to telemetric monitoring, and may continue to do so for at least 4 years (Schmid 1998).
Further studies could determine whether turtles return to previously used sites within the study area. Between season home-range areas could be investigated by re-instrumenting turtles over consecutive years and comparing their locations each year. However, the probability of recapturing an instrumented turtle between seasons is low. Such an endeavor would require a larger sample size of instrumented turtles and intensive netting efforts in subsequent years.

\section{Habitat Use}

Kemp's ridley turtles are benthic carnivores and as such would be expected to use the habitats of their prey. Blue crab (Callinectes sapidus) and stone crab (Menippe spp.) were prominent food items of subadult turtles captured near the Cedar Keys (Schmid 1998). Both crabs have been collected from a variety of benthic substrates and biological assemblages, but seagrass (McRae 1950, Menzel and Nichy 1958, Eggleston 1990) and oyster reef (Bender 1971, Orth and van Montfrans 1990) habitat use has been noted for both species. However, Kemp's ridley turtles in our study did not exhibit a high degree of seagrass or oyster habitat use, as has been inferred in other studies. Furthermore, compositional analyses indicated a preference for rock bottom, and the flora and fauna associated with this bottom type, which has not been suggested in any previous tagging (Ogren 1989, Rudloe et al. 1991, Schmid 1998) or telemetry studies (Byles 1988, Danton and Prescott 1988). The unexpected preference for rock bottom may reflect a greater prey abundance in the live-bottom habitat. Many 
decapod crustacean species, the primary prey of Kemp's ridley turtles, use sessile invertebrate colonies such as corals, tunicates, sponges, and bryozoans (Collard and D'Asaro 1973, Lindberg and Stanton 1988).

Most Kemp's ridley turtles' fecal samples collected in the Cedar Keys contained chelipeds of either stone crabs or blue crabs, but not both (J. R. Schmid, National Marine Fisheries Service, unpublished data). Individual turtles may feed selectively on a single crab species, which may account for the variation in habitat use within the study area. Turtles using hard-bottom assemblages may have been foraging on stone crabs, whereas turtles using soft-bottom assemblages may have been foraging on blue crabs. However, prey species' habitat preferences have not been established. Habitat use/availability data could be collected for the $2 \mathrm{crab}$ species to examine their habitat preferences in the study area. Furthermore, the possibility of habitat-specific prey selection could be investigated by establishing turtle habitat use via telemetric monitoring and then recapturing these individuals to analyze fecal contents. Areas used by instrumented turtles could be sampled to estimate prey availability. Compositional analyses could be applied to determine whether the turtles are exhibiting both habitat and food preferences.

\section{Seasonal Shifts in Habitats}

Telemetric data indicate that subadult Kemp's ridley turtles along the U.S. Atlantic and Gulf coasts migrate offshore and southward during winter months (Renaud 1995, Gitschlag 1996). Post-nesting females migrate to offshore areas in the northern and southern Gulf (Byles 1989) where they presumably overwinter. However, no data are available on the offshore habitats used by this species. The preference for nearshore hard-bottom communities observed in our study may have important implications for offshore winter habitat use by subadults and adults. Livebottom communities occur on a variety of hard substrates in the shelf waters of the southeast United States. (Collard and D'Asaro 1973, Rezak et al. 1985, Brooks 1991, Jaap and Hallock 1990). These offshore areas have a warm-temperate environment during the winter and may provide winter refuge for subadult Kemp's ridley turtles. Similarly, adults may be utilizing hard-bottom habitats in the northern Gulf, and those on the Yucatan-Campeche Shelf in the southern Gulf, as foraging grounds between nesting seasons. Satellite telemetry could be used to identify the offshore areas used by subadults and adults, and benthic sampling could be conducted in these areas to map the available bottom types.

\section{Implications for Other Life Stages}

Ogren (1989) characterized Kemp's ridley turtles' life history according to ontogenetic shifts in habitat use: an epipelagic juvenile stage $(<20 \mathrm{~cm}$ straight-line carapace length [SCL; nuchal notch to tip of postcentral scutes]), a nearshore coastalbenthic subadult stage (20-60 $\mathrm{cm}$ SCL), and an offshore coastal-benthic adult stage $(>60 \mathrm{~cm}$ SCL). Kemp's ridley turtles inhabiting the Cedar Keys area have been characterized as mid to late subadults (mean $=44.5 \mathrm{~cm}$ SCL; Schmid 1998), and the instrumented turtles of our study were in this size class. Significantly smaller sized Kemp's ridley turtles were captured approximately $75 \mathrm{~km}$ northwest of our study area in Deadman Bay, Florida (mean = $32.7 \mathrm{~cm}$ SCL; Barichivich 1998). Capture data indicate that these early- to midsubadult turtles are using seagrass habitat and feeding on spider crabs (Libinia spp.). Smaller Kemp's ridley turtles may select the shallow seagrass habitat owing to protection from predators (e.g., sharks). Morreale and Standora (1998) suggested that post-pelagic Kemp's ridley turtles recruiting to the benthic environment feed selectively on slower-moving spider crabs rather than more abundant and faster-swimming lady (Ovalipes ocellatus) and blue crabs. The food habits of $L$. emarginata have been described as herbivorous (Ropes 1988), but no data indicate that spider crabs prefer seagrass habitat. Further studies are needed to investigate resource selection by smaller Kemp's ridley turtles and their prey.

Larger subadult Kemp's ridley turtles also could use the seagrass habitat but develop a preference for nearshore hard-bottom communities. This may be an innate habitat preference or a response to prey distribution. The shift in habitat use may also correspond to the onset of pubertal changes. Gregory and Schmid (2001) indicated that Kemp's ridley turtles may begin maturing at approximately $40 \mathrm{~cm} \mathrm{SCL}$, and reclassified Ogren's (1989) coastal-benthic immature stage as a $20-40$ cm pre-pubertal stage and a $40-60 \mathrm{~cm}$ pubertal stage. Correspondingly, pre-pubertal turtles in the northeastern Gulf may prefer seagrass communities, whereas the maturing turtles in the Cedar Keys prefer epibenthic communities associated with hard bottom. Mature turtles shift their habitat use to offshore areas, as they are not captured at nearshore study sites. Future tele- 
metric studies could include early subadult and adult turtles to investigate the possibility of sizespecific habitat and depth preferences by Kemp's ridley turtles. Long-term and concurrent tagging studies also are needed to demonstrate ontogenetic shifts in habitat utilization and the subsequent coupling among habitat types.

\section{MANAGEMENT IMPLICATIONS}

The number of nesting Kemp's ridley turtles has steadily increased in recent years, presumably because of the protection of primary nesting beach and restrictions designed to decrease mortality in commercial fisheries (Márquez et al. 2001, Turtle Expert Working Group 1998). Increases in the number of hatchlings released from the hatchery program have presumably led to increased subadult turtle numbers in U.S. coastal waters (Ogren 1989, Schmid 1998). As subadult abundance continues to increase, availability of preferred habitat and prey will become increasingly important for maintaining a viable population of Kemp's ridley turtles. Our study is the first to conduct a detailed habitat-preference analysis for Kemp's ridley turtles and the benthic habitats in which they forage. Similar studies are needed throughout their distribution to investigate regional and developmental differences in availability, use, and preference of both habitat and prey. Conservation plans can then incorporate these study results to protect or enhance the preferred resources of Kemp's ridley turtles.

A major concern in the recovery of this endangered species is habitat degradation resulting from coastal development, industrial pollution, channel construction and maintenance, and petroleum exploration and extraction (U.S. Fish and Wildlife Service and National Marine Fisheries Service 1992). A number of coastal areas in the United States already are protected as federal and state lands. Our study area was bounded by the Cedar Keys National Wildlife Refuge and the Waccasassa Bay State Preserve. Conservation of marine habitat in Florida has focused on the protection of coral reefs and seagrass beds, the latter of which would benefit smaller subadult Kemp's ridley turtles. However, stage-based population models indicate that reducing the mortality of large juvenile and subadult stages is the key to long-term survival of marine turtle populations (Crouse et al. 1987). Accordingly, management plans for the Kemp's ridley turtle should consider the nearshore hard bottom areas that are preferred by larger turtles.

\section{ACKNOWLEDGMENTS}

We thank L. H. Ogren and W. N. Witzell for their support; Mr. and Mrs. E. Campbell for allowing unrestrained use of their facilities in Cedar Key; and W. J. Barichivich, M. Cherkiss, J. T. Collins, and L. F. Gregory for their exemplary field assistance. Funding for this project was provided by the National Marine Fisheries Service (NMFS) Panama City and Miami Laboratories and NMFS grants to the Archie Carr Center for Sea Turtle Research. Research activities were conducted under U.S. Fish and Wildlife Service permit PRT-67379 and Florida Department of Environmental Protection permit \#030. All animal care was in full compliance with the University of Florida Institutional Animal Care and Use Committee. This research was supported by the Florida Agricultural Experiment Station, and approved for publication as Journal Series No. R09146.

\section{LITERATURE CITED}

Ackerman, B. B., F. A. Leban, M. D. Samuel, and E. O. GARTON. 1990. User's manual for program HOMF RANGE, second edition. Technical Report 15, Forestry, Wildlife and Range Experiment Station, University of Idaho, Moscow, USA.

AEbischer, N. J., P. A. Robertson, AND R. E. KeNWARD. 1993. Compositional analysis of habitat use from animal radio-tracking data. Ecology 74:1313-1325.

AItchison, J. 1986. The statistical analysis of compositional data. Chapman \& Hall, New York, USA.

AMERICAN SOCIETY FOR TESTING AND MATERIAIS (ASTM). 1993. Standard test method for the amount of materials in soils finer than the no. $200(75 \mu \mathrm{m})$ sieve. Pages 191-193 in Annual book of ASTM standards, section 4, volume 04.08. ASTM, Philadelphia, Pennsylvania, USA.

BARICHIVICH, W. J. 1998. Feeding ecology and habitat affinities of Kemp's ridley sea turtles (Lepidochelys kempi) in the Big Bend, Florida. Annual report to National Marine Fisheries Service, Panama City, Florida, USA.

Bender, E. S. 1971. Studies of the life history of the stone crab, Menippe mercenaria (Say), in the Cedar Key area. Thesis, University of Florida, Gainesville, USA.

Brooks, J. M., editor. 1991. Mississippi-Alabama continental shelf ecosystem study: data summary and synthesis, volume I: executive summary. OCS Study MMS 91-0062. U.S. Department of the Interior, Minerals Management Service, Gulf of Mexico OCS Regional Office, New Orleans, Louisiana, USA.

Byles, R. A. 1988. Behavior and ecology of sea turtles from Chesapeake Bay, Virginia. Dissertation, Virginia Institute of Marine Science, College of William and Mary, Williamsburg, USA.

1989. Satellite telemetry of Kemp's ridley sea turtle, Lepidochelys kempi, in the Gulf of Mexico. Pages 25-26 in S. A. Eckert, K. L. Eckert, and T. H. Richardson, compilers. Proceedings of the Ninth Annual Workshop on Sea Turtle Conservation and Biology. 
NOAA Technical Memorandum NMFS-SEFC-232.

Carroll, J. P., R. D. Crawford, AND J. W. Schulz. 1995 Gray partridge winter home range and use of habitat in North Dakota. Journal of Wildlife Management 59:98-103.

Coll ARD, S. B., AND C. N. D'Asaro. 1973. The biologica environment: benthic invertebrates of the eastern Gulf of Mexico. Pages IIIG-1-IIIG-27 in J. I. Jones, R. E. Ring, M. O. Rinkel, and R. E. Smith, editors. A summary of the knowledge of the eastern Gulf of Mexico. State University System of Florida, Institute of Oceanography, St. Petersburg, USA.

Continental Shelf Associates, INC., AND Martel LabORATORIES INC. 1985. Florida Big Bend seagrass habitat study narrative report. A final report by Continental Shelf Associates, Inc. submitted to the Minerals Management Service, Metairie, Louisiana, USA. Contract No. 14-12-001-30188.

Crouse, D. T., L. B. Crowder, and H. Caswell. 1987. A stage-based population model for loggerhead sea turtles and implications for conservation. Ecology 68:1412-1423.

Danton, C., And R. Prescott. 1988. Kemp's ridley in Cape Cod Bay, Massachusetts-1987 field research. Pages 17-18 in B. A. Schroeder, compiler. Proceedings of the Eighth Annual Workshop on Sea Turtle Conservation and Biology. NOAA Technical Memorandum NMFS-SEFC-214

EgGLESTON, D. B. 1990. Foraging behavior of the blue crab, Callinectes sapidus, on juvenile oysters, Crassosirea virginica: effects of prey density and size. Bulletin of Marine Science 46:62-82.

ENVIRONMENTAL. SYSTEMS RESEARCH INSTITUTE. (ESRI). 1992-1996. ARCVIEW GIS 3.0. ESRI, Redlands, California, USA.

GITSCHIAG, G. R. 1996. Migration and diving behavior of Kemp's ridley (Garman) sea turtles along the U.S southeastern Atlantic coast. Journal of Experimental Marine Biology and Ecology 205:115-135.

Gregory, L. F., AND J. R. SCHMid. 2001. Stress responses and sex ratio of wild Kemp's ridley sea turtles (Lepi dochelys kempi) in the northeastern Gulf of Mexico. General and Comparative Endocrinology 124:66-74.

Hildebrand, H. H. 1982. A historical review of the status of sea turtle populations in the western Gulf of Mexico. Pages 447-453 in K. A. Bjorndal, editor. Biology and conservation of sea turtles. Smithsonian Institution Press, Washington, D.C., USA.

JaAP, W. C., AND P. Hallock. 1990. Coral reefs. Pages 574-616 in R. L. Myers and J. J. Ewel, editors. Ecosystems of Florida. University of Central Florida Press, Orlando, USA.

JOHNSON, D. H. 1980. The comparison of usage and availability measurements for evaluating resource preference. Ecology 61:65-71.

LAMBE, T. W., AND R. V. WHITMAN. 1969. Soil mechanics. Wiley, New York, USA.

L.INDBERG, W. J., AND G. STANTON. 1988. Bryozoan-associated decapod crustaceans: community patterns and a case of cleaning symbiosis between a shrimp and a crab. Bulletin of Marine Science 42:411-423.

Magnuson, J. J., K. A. BJoRndal, W. D. DuPaul, G. L. Graham, D. W. Owens, C. H. Peterson, P. C. H. Pritchard, J. I. Richardson, G. E. SAUl, AND C. W. West. 1990 Decline of the sea turtles: causes and prevention. National Academy Press, Washington D.C., USA.
Márquez, R., P. Burchfield, M. A. Carrasco, C. Jiménez, J. díaz, M. Garduño, A. Leo, J. Peña, R. Bravo, and E. GONZÁlEZ. 2001. Update on the Kemp's ridley turtle nesting in México. Marine Turtle Newsletter 92:2-4.

MCRAE, E. D., JR. 1950. An ecological study of the xanthid crabs in the Cedar Key area. Thesis, University of Florida, Gainesville, USA.

MENZEL, R. W., AND F. E. NiCHY. 1958. Studies of the distribution and feeding habits of some oyster predators in Alligator Harbor, Florida. Bulletin of Marine Science of the Gulf and Caribbean 8:125-145.

Miller, D. A., G. A. Hurst, AND B. D. Leopold. 1999. Habitat use of eastern wild turkeys in central Mississippi. Journal of Wildlife Management 63:210-222.

MORREAlE, S. J., AND E. A. STANDORA. 1998. Early life stage ecology of sea turtles in northeastern U.S. waters. NOAA Technical Memorandum NMFS-SEFSC 413.

OGREN, L. H. 1989. Distribution of juvenile and subadult Kemp's ridley turtles: preliminary results from the 1984-1987 surveys. Pages 116-123 in C. W. Caillouet, Jr. and A. M. Landry, Jr., editors. Proceedings of the First International Symposium on Kemp's Ridley Sea Turtle Biology, Conservation, and Management. TAMU-SG-89-105. Texas A \& M University Sea Grant College Program, College Station, USA.

ORTH, R. J., AND J. VAN MONTFRANS. 1990. Utilization of marsh and seagrass habitats by early stages of Callinectes sapidus: a latitudinal perspective. Bulletin of Marine Science 46:126-144.

OTT, P., AND F. HoveY. 1997. BYCOMP.SAS, version 1.0. http://nhsbig.inhs.uiuc.edu/habitat_use/bycomp.sas. Porter, W. F., AND K. E. CHURCH. 1987. Effects of environmental pattern on habitat preference analysis. Journal of Wildlife Management 51:681-685.

RENAUD, M. R. 1995. Movements and submergence patterns of Kemp's ridley turtles (Lepidochelys kempii). Journal of Herpetology 29:370-374.

REZAK, R., T. J. BRIGHT, AND D. W. MCGRAIL. 1985. Reefs and banks of the northwestern Gulf of Mexico. Wiley, New York, USA.

Ropes, J. W. 1988. The food habits of five crab species at Pettaquamscutt River, Rhode Island. Fishery Bulletin 87:197-204.

RudloE, A., J. RudLOE, ANd L. OGREN. 1991. Occurrence of immature Kemp's ridley turtles, Lepidochelys kempi, in coastal waters of northwest Florida. Northeast Gulf Science 12:49-53

SAS INSTITUTE. 1989. SAS/STAT user's guide, version 6 , fourth edition, volume 2. SAS Institute, Cary, North Carolina, USA.

SCHMID, J. R. 1998. Marine turtle populations on the west-central coast of Florida: results of tagging studies at the Cedar Keys, Florida, 1986-1995. Fishery Bulletin 96:589-602.

2000. Activity patterns and habitat associations of Kemp's ridley turtles, Lepidochelys kempi, in the coastal waters of the Cedar Keys, Florida. Dissertation, University of Florida, Gainesville, USA. http://www.uflib.ufl.edu/etd.html.

A. B. BOlten, K. A. BJORNDAL, AND W. J. LINDBERG. 2002. Activity patterns of Kemp's ridley turtles, Lepidochelys kempii, in the coastal waters of the Cedar Keys, Florida. Marine Biology 140:215-228.

Thomas, D. L., AND E. J. TAYloR. 1990. Study designs and tests for comparing resource use and availability. Journal of Wildlife Management 54:322-330. 
Thompson, N., T. Henwood, S. EPPerly, R. LOHOEFner, G. Gitschlag, L. OgRen, J. Mysing, ANd M. Renaud. 1990. Marine turtle habitat plan. NOAA Technical Memorandum NMFS-SEFC-255.

TURTLE EXPERT WORKING GROUP. 1998. An assessment of the Kemp's ridley (Lepidochelys kempii) and loggerhead (Caretta caretta) sea turtle populations in the western North Atlantic. NOAA Technical Memorandum NMFS-SEFSC-409.

U.S. Fish and Wildilfie Service and National Marine FISHERIES SERVICE. 1992. Recovery plan for the Kemp's ridley sea turtle (Lepidochelys kempii). National Marine
Fisheries Service, St. Petersburg, Florida, USA.

WHTTE, G. C., AND R. A. GARROTT. 1990. Analysis of wildlife radio-tracking data. Academic Press, New York, USA. WOLFE, S. H., editor. 1990. An ecological characterization of the Florida Springs Coast: Pithlachascotee to Waccasassa rivers. U.S. Department of Interior Biological Report 90.

Received 2 November, 2001.

Accepted 9 October 2002.

Associate Editor: Russell. 